\title{
THE PRACTICE AND CHALLENGES OF IMPLEMENTING CRITICAL THINKING SKILLS IN EFL TEACHERS' QUESTIONING BEHAVIOR
}

\author{
Ahmad Zainudin \\ Department of English Language Education, Faculty of Teacher Training and Education, \\ Sriwijaya University, Indonesia \\ Email: ahmadzain04@gmail.com \\ Machdalena Vianty (Corresponding Author) \\ Department of English Language Education, Faculty of Teacher Training and Education, \\ Sriwijaya University, Indonesia \\ Email: vianty.unsri@gmail.com \\ Rita Inderawati \\ English Language Education, Faculty of Teacher Training and Education, \\ Sriwijaya University, Indonesia \\ Email: ritarudisaid@yahoo.com
}

\begin{abstract}
APA Citation: Zainudin, A., Vianty, M., \& Inderawati, R. (2019). The practice and challenges of implementing critical thinking skills in EFL teachers' questioning behavior. English Review: Journal of English Education, 8(1), 51-58. doi: 10.25134/erjee.v8i1.2112.
\end{abstract}

\begin{abstract}
The development of critical thinking is closely related to the questions asked by teachers as the teachers' higher-order questions are cognitively demanding to promote students' critical thinking. The purposes of this study are to investigate how critical thinking was implemented in EFL teachers' questions in the classroom and the challenges faced by EFL teachers in integrating critical thinking questions. In addition, this study also investigated students' reasons for non-response to particular questions asked by teachers. Applying mixed-method research design, the data were collected from classroom observation, interview, questionnaire and documentations. The research participants were two English teachers and 229 number of students of year 8 . The results showed that the most dominant questions asked by the two English teachers were in Lower-order questions $(78,8 \%)$, while the Higher-order questions were only $(21,2 \%)$ questions. Second, the challenges faced by teachers were students' intelligence has yet to reach the level of higher-order thinking, unconducive-classroom environment, teachers' creativity itself, parental involvement and students' lack of vocabulary. Third, dealing with the reason for students' non-response in particular questions asked by teachers, there were some reasons, such as students are afraid of making mistakes, they could not put ideas into words, and lack of vocabularies. In conclusion, the teachers faced various challenges in implementing critical thinking questions in the classroom.

Keywords: critical thinking; critical thinking questions; lower-order questions; higher-order questions; the challenges; students' non-response.
\end{abstract}

\section{INTRODUCTION}

Critical thinking is a significant topic in one of the primary goals of education in the $21^{\text {st }}$ century. National Education Association of the United States (2012) reveals that teachers should prepare students for the new global society by incorporating the 'Four Cs', including critical thinking, communication, collaboration, and creativity. Yet, this study was focused on critical thinking. National Education Association of the United (2012, p. 8) states, "teaching critical thinking and problem solving effectively in the classroom is vital for students. Learning critical thinking leads students to develop other skills, such as a higher level of concentration, deeper analytical abilities, and improved thought processing."

The development of students' critical thinking is related to the questions asked by teachers because the teachers' questions are important features in the classroom. Richards and Schmidt (2010) state that questioning behavior is one of the most frequently used teaching techniques to encourage classroom interaction. Moreover, Bloom (1956) asserts that asking questions that are cognitively demanding is an effective means to enhance students' critical thinking.

In line with Bloom's theory, Peraturan 
Menteri Pendidikan dan Kebudayaan Indonesia No. 22 of 2016 about Standard Process states that 2013 curriculum also adopts a learning approach based on the taxonomic theory that includes three competency domains, namely affective, cognitive, and psychomotor (Indonesia Ministry of Education, 2016). Critical thinking is instilled in the 2013 curriculum that can be seen from the adoption of Bloom's theory from the least to most difficult cognitive domains as teachers need to promote critical thinking by asking questions in order to encourage students to produce creative and contextual work, both individually and in groups (Indonesia Ministry of Education, 2016).

The 2013 curriculum has also done efforts to answer the challenges of global citizenship education in which it is also associated with $21^{\text {st }}$ century characteristics, namely critical thinking, since 2013 curriculum is implemented by using the scientific approach. In addition, scientific approach covers the following steps: (1) observing - identifying problem, (2) questioning - formulating the problems to develop critical thinking, (3) collecting - collecting materials or data in various learning ways, (4) associating - to analyze and make conclusions, and (5) communicating - developing students' knowledge and skill in delivering ideas clearly (Indonesia Ministry of Education, 2013).

In line with the objectives of the Indonesia National Education, the government has also included critical thinking as a necessary skill in every level grade of education, especially for junior high school level (Indonesia Ministry of Education, 2010). Teachers are supposed to develop students to think critically, share an idea, and make better judgments.

The accreditation instrument of public high school (BAN S/M, 2017) clearly states in Item No 41 the specific standards for teachers as follows: teachers should have pedagogical competence to which is in relation to promote critical thinking skills that include the rule of learning principles, the design and the implementation of learning, and communication skills with students. In addition, learning activities such as involving group discussion, reading articles or watching videos, then answering questions are designed to encourage the development of critical thinking and social skills by exploring values, supporting content knowledge and developing practical skills (UNESCO, 2015).

In terms of teachers' competency, Indonesia government has already done Uji Kompetensi
Guru $(U K G)$ in 2015. Unfortunately, based on The $U K G$ results, most teachers were still below standard required. Mean score for pedagogical competence was 48.94, meanwhile, the passing grade should be 55 (Indonesia Ministry of Education, 2015). By looking at the data, pedagogical competence needed to be updated by teachers towards content knowledge and skills. Teachers might also join the seminar, in house training, MGMP (Musyawarah Guru Mata Pelajaran), or PPG (Pendidikan Profesi Guru) in which these forums help teachers to discuss the latest issue of education system and as a place to share idea how to teach students in the $21^{\text {st }}$ century, especially to promote critical thinking.

Based on the observation of one of the researchers (functioning as the teacher) in joining $M G M P$ group 7 of junior high school of Palembang, most of the teachers involved in $M G M P$ group 7 got difficulties in promoting critical thinking through questioning. It could be seen from the lesson plan they made that they were a lack of knowledge to fulfill the indicator of higher-order thinking skills. They only fulfilled C2: Comprehension. Furthermore, based on the discussion during the training, most of the teachers claimed they had not applied higherorder questioning yet. It was assumed that teachers were still a lack of understanding to promote critical thinking in the classroom.

Similarly, there was a discrepancy between what should be done and what had been practiced teachers' questioning behaviors to promote critical thinking in the language classroom. Some studies related to teachers' questions were conducted in Indonesia context. For example, Yuliawati, Mahmud, and Muliati (2016) found out in Makasar that teachers mostly asked $85.18 \%$ knowledge questions and never asked synthesis and evaluation questions as higherorder thinking levels in the classroom. Katemba and Marie (2016) also did research in Bandung with six different English teachers, reported that the most type of the questions that had been used is under lower-order questions with $67.3 \%$ and $46.53 \%$ belongs to knowledge level which teachers only asked about the definition of the topics, the meaning, and the translation.

In terms of document analysis of lesson plan, Purnawarman, Ratnaningsih, and Gunawan (2017) found out in Bandung Regency that teachers were lack of understanding to decide learning indicator, in the same way, they only fulfilled the indicators by using $\mathrm{C} 2$ : Comprehension. It was focused on lower-order 
thinking might not give a contribution to the development of students' cognitive skill in analysis, synthesis, and evaluation. As a result, in classroom observation teachers kept asking related questions trying to have active learning and develop students' thinking skills but it was not achieved well.

Matra (2014) reported in Pekalongan that students were faced with problems in understanding difficult words of questions, therefore, teachers needed to repeat their questions to clarify the meaning or translated it into Bahasa Indonesia. It is in line with international education company English First (EF, 2017) reports that Indonesia students' English proficiency were still low level. They found out that Indonesia was in the $39^{\text {th }}$ rank out of 80 countries participated in the Survey. Unfortunately, Indonesia had fallen seven spots from the previous year, when it was ranked $32^{\text {nd }}$ out of 72 countries.

In relation to the explanation above, the aim of this study was to investigate how critical thinking was implemented in EFL teachers' questions in the classroom and the challenges faced by EFL teachers in integrating critical thinking questions. In addition, this study also investigated students' reasons for non-response to particular questions asked by teachers.

\section{METHOD}

Applying mixed-method research design, the research site was at SMPN 20 Palembang. The research participants were two English teachers who are the members of MGMP (Musyawarah Guru Mata Pelajaran) Group 7. However, the two English teachers were selected based on the following criteria: first, the teachers who hold a Master degree majoring in English Education Study Program; second, the teachers who have been certified and graduated from S1 degree majoring in English education study program, and third, the teachers who have been teaching more than 10 years. This study also involved 229 number of eighth-grade students consisting of eight classes in academic year 2018/2019 where the English teachers as the participants in this study taught.

The data were collected from classroom observation, interview, questionnaire and documentations. To investigate how critical thinking was implemented in EFL teachers' questions in the classroom, observation sheet given by Wilen (1991) that consists of six levels of questions in the original Bloom Taxonomy which categorized based on four levels of questions classification; (1) level 1 of low order convergent in knowledge level, (2) level 2 of high order convergent in comprehension and application levels, (3) level 3 of low order divergent in analysis level, (4) level 4 of high order divergent in synthesis and evaluation levels. The convergent questions are to assess Lower-order thinking process. While, divergent questions are to promote Higher-order thinking process. The observation was recorded and the data was analyzed into percentages and interpreted descriptively.

Interview schedule - face to face was constructed to the two English teachers. This study provided one prompt question to know the challenges faced by the English teachers in integrating critical thinking questions in the classroom. In addition, the questionnaire was distributed to the students to get information about the reasons why students did not respond to teachers' questions. The questionnaire was adopted from Natthanan (2009) which were classified into three different categories, as follows: (1) the students understood teachers' questions but they could not answer them, (2) the students understood teachers' questions, knew the answers but they did not answer them, (3) the students did not understand teachers' questions and they could not answer.

The students were only required to select one category that matched their reason for their nonresponse, then the students were only required to answer one cause and write their comments to enhance discussion of the result of their reason for non-response within the category they selected. The data was analyzed into percentages and interpreted descriptively. To support the data, document checklist was used to be the available information in relation to critical thinking questions applied by the two English teachers.

\section{RESULTS AND DISCUSSION}

The research findings showed that four levels of questions classification (Wilen, 1991) appeared in questions asked by the two English teachers namely; level 1 of Low Order Convergent (Knowledge Level), level 2 of High Order Convergent (Comprehension and Application Levels), level 3 of Low Order Divergent (Analysis Level), and level 4 of High Order Divergent (Synthesis and Evaluation Levels).

However, the percentages at each level of questions asked by the two English teachers are different. From the total of 405 questions, the 
highest percentage is in Lower-order questions (78,8\%), while the Higher-order questions were only $(21,2 \%)$ questions. It can be concluded that the most dominant questions asked by the two English teachers were in Lower-order questions. Table 1 presents the findings in detail.

Table 1. The classification of teachers' questions based on the observation

\begin{tabular}{cccc}
\hline No & Levels of lower-order Questions & Total & Percentage \\
\hline 1 & Level 1 - Low Order Convergent & 199 & $49,13 \%$ \\
2 & Level 2 - High Order Convergent & 120 & $29,62 \%$ \\
& Total & 319 & $78,8 \%$ \\
No & Levels of Higher-order Questions & Total & Percentage \\
3 & Level 3 - Low Order Divergent & 56 & $13,82 \%$ \\
4 & Level 4 - High Order Divergent & 30 & $7,40 \%$ \\
& Total & 86 & $21,2 \%$ \\
& Total of All Questions & 405 & $100 \%$ \\
\hline
\end{tabular}

In relation to the questions asked by the teachers in four levels of questions classification, the following data provides information about it:

Most dominant questions were in Level 1 $(49,13 \%)$ which refers to Knowledge Level questions. At this level, the students are expected to store and remember certain information in the learning process as presented in Data 1.

Data 1:

- Give an example of things that can be compared?

- He is tall, isn't he? and the next?

- What did you do at 6 this morning?

- What is the meaning of the event?

In addition, there were $(29,62 \%)$ Level 2 in Comprehension and Application Levels questions. These levels require students to perform better understanding then apply the knowledge to the appropriate situation as presented in Data 2.

Data 2:

- What is 'Tinggi' in English? Indicate to pronounce words tall, taller, and tallest

- Find the past tense in this text and underline the words!

- We have three dictionaries, make a sentence which one is 'Lebih tebal' or 'Paling tebal'

- I give you one verb 'Wake up' find out the v2 and make sentence by using that verb for past tense lesson

Furthermore, there were $(13,82 \%)$ Level 3 in Synthesis Level questions that require students to analyze a problem, give reasoning and support the argument as presented in Data 3.

Data 3:

- How do you explain the relationship between suffix-er and -est?

- What is the relationship between suffix -more and-most?

- Classify the text based on daily activities in the form of past tense?

The last, there were $(7,40 \%)$ Level 4 in
Evaluation and Synthesis Levels questions. This level demands students to come up with better solutions for certain problems then produce innovative ideas to act as presented in Data 4.

Data 4:

- What would happen if the adjective had only three syllables, not two syllables? Then, create the sentence to compare something in our school context

- Give me the right form or what can we combine in making past tense with verb and be? Please, create your activity yesterday in front of the class by using past tense?

- What do you think of the lesson today? Give some summary or conclusion

The finding of this research is similar to research conducted in Indonesia by Katemba and Marie (2016) who did a research in Bandung with six different junior high schools English teachers. They reported that the most type of the questions asked by English teachers grouped into Lower-order questions (67.3\%). Moreover, Khan and Inamullah (2011) who conducted study in Pakistan secondary school by involving twenty teachers also found that the ratio of Higher-order questions asked by the teachers was very low (20\%).

The two English teachers still focused on Lower-order questions because based on results of the interview, the teachers state that the level of students' intelligence has yet to reach the level of Higher-order thinking.

Teacher 1:

"First student intelligence itself as initial input besides that there is another thing that is whether or not English is one of their favorite lessons."

Teacher 2:

"Inviting students to think critically is difficult because there are only a few children who are smart and they like asking questions. Most students are asked whether or not they understand, they answer yes. Are there any questions? No. Most of them." 
This finding coincides with the result of the study conducted by Sholikhati, Mardiyana, and Saputro (2017), they found that high personal intelligence students can achieve analyzing thinking level, students with moderate personal intelligence being able to reach the level of applying thinking, and students with low personal intelligence able to reach understanding level. It can be assumed that most of students' participants in this study were in moderate intelligence. However, the teachers still asked a Higher-order question even if a little. This means that the teachers have already known and implemented Higher-order questions although the percentage was very low.

In terms of teachers' implementation, the two English teachers started with the basic level of questions, for example, the definition of the lessons, the meaning of the words, translation and ended questions which can be simply answered by saying 'yes' or 'no' (See Data 1 and Data 2). Most of the students were enthusiastic to answer questions even they were asked to open a dictionary because they did not need more explanation. As stated by Bloom (1956) that Lower Cognitive questions represent the lowest level of understanding which required students to recall previous knowledge directly instead of any process of manipulating knowledge.
However, it does not mean that the role of teachers' asking questions in Lower-order thinking could not promote students' critical thinking, because it could drive students to think critically. Teachers gave repetitive questions, feedback and promoted follow-up questions after they asked basic questions to lead students' critical thinking (See Data 3 and Data 4). It was also stated in an interview that the two English teachers firstly asked Lower-order questions to check students' basic knowledge then Lowerorder questions could lead to Higher-order questions. As stated by Wilen (2001) that Lowerorder questions can prepare learners for Higherorder questions. It is similar to a study conducted by Sano (2014) who found that Lower-order questions tended to be focused on basic questions while Higher-order questions seemed to focus on follow-up questions.

From the students' point of view, based on observation students is silence when asked in Higher-order questions because teachers invited students to have discussion to relate the material in deep and meaningful way. It is supported by the result of questionnaire that the cause of students' silence because they were afraid of making mistakes $(32,31 \%)$. The result of questionnaire is presented in Table 2 .

Table 2. The causes of students' responses to the questionnaire

\begin{tabular}{|c|c|c|c|c|}
\hline \multirow[t]{2}{*}{ No } & \multirow{2}{*}{$\begin{array}{c}\text { Why did not } \\
\text { students respond to } \\
\text { teachers' questions? }\end{array}$} & \multirow[t]{2}{*}{ Causes } & \multicolumn{2}{|c|}{$\begin{array}{c}\text { Student's response to } \\
\text { questionnaire }\end{array}$} \\
\hline & & & $\mathbf{N}$ & Percentage $(\%)$ \\
\hline \multirow[t]{6}{*}{1} & \multirow{6}{*}{$\begin{array}{l}\text { Students understood } \\
\text { teachers' questions, } \\
\text { knew the answers, but } \\
\text { they did not answer }\end{array}$} & Students were afraid of making mistakes & 74 & $32,31 \%$ \\
\hline & & Students were shy & 22 & $9,60 \%$ \\
\hline & & $\begin{array}{l}\text { Students were having difficulty concentrating in class or } \\
\text { occupied with a personal problem }\end{array}$ & 10 & $4,37 \%$ \\
\hline & & Students waited for answers from the teachers & 9 & $3,93 \%$ \\
\hline & & Students did not like speaking English. & 7 & $3,05 \%$ \\
\hline & & Students did not like to talk in class & 6 & $2,62 \%$ \\
\hline \multirow[t]{5}{*}{2} & \multirow{5}{*}{$\begin{array}{l}\text { Students understood } \\
\text { teacher's questions, } \\
\text { but they could not } \\
\text { answer }\end{array}$} & Students could not put ideas into words. & 31 & $13,53 \%$ \\
\hline & & Students did not know the vocabulary. & 17 & $7,42 \%$ \\
\hline & & Students did not know the grammar. & 13 & $5,7 \%$ \\
\hline & & $\begin{array}{l}\text { Students did not have the knowledge required by the } \\
\text { questions. }\end{array}$ & 9 & $3,93 \%$ \\
\hline & & $\begin{array}{l}\text { The teachers did not give sufficient time to formulate } \\
\text { the answer. }\end{array}$ & 3 & $1,31 \%$ \\
\hline \multirow[t]{4}{*}{3} & \multirow{4}{*}{$\begin{array}{l}\text { Students did not } \\
\text { understand teachers' } \\
\text { questions, and they } \\
\text { could not answer }\end{array}$} & The content was too difficult and complex & 20 & $8,73 \%$ \\
\hline & & The teacher used vocabulary that was too difficult & & \\
\hline & & & 8 & $3,5 \%$ \\
\hline & & TOTAL & 229 & $100 \%$ \\
\hline
\end{tabular}

In relation to the students' comments after indicating cause they chose, the result found that most of the students were not convinced of their answer. The students showed their friends instead of directly answer questions. It is also possible if the classroom-environment could lead them to be not confident with their English and fear to be joked by the other friends.

Based on the statements above, it could be pointed out that the lack of confidence could 
affect students' exposure to speak in the class that can lead thinking critically. The students must have an opportunity to talk without feeling afraid to do some mistakes. Especially, they are in language class which encourages them to deliver what were on their mind. This can be done by building a good classroom-environment.

It was supported by the interview, both teachers said that the unconducive-classroom environment was also a factor that influenced teachers to promote students' critical thinking. Therefore, a good classroom environment must be available to make the students feel positive emotions. The following are the statements from the teachers:

Teacher 1:

"In promoting critical thinking also depends on the classroom environment. For example, the class that begins the lesson in afternoon 10.40-12.00, they have not been focus to study. Therefore, the teacher plays a role to improve their mood, through work up activities to make them feel welcome in the class."

Teacher 2:

"Actually, all the classes I teach are active, but there are two classes 8.8 and 8.7, they are rather noisy so I sometimes have to control the class."

According to Slameto (2003), to achieve a good command in English for students is caused by two factors that can be divided into internal and external. Internal usually comes from the students themselves like lack of self-confidence. While external comes from the classroom environment. The unconducive-classroom environment like being laughed by their friends who gave incorrect answers that this such atmosphere would make them afraid to answer the teachers' questions. The researchers assumed that this can be associated with the culture of the city where this study conducted.

This finding is in line with the result of study conducted by Rahmi and Diem (2014) who did research in Palembang with 55 state junior high schools. They reported that classroom environment is correlated positively to students' English achievement. Therefore, a good classroom environment must be available in every school, especially for junior high schools whose students are in the age of growing not only physically but also psychologically, they are sometimes being confused about what they have to and not to do.

This also can be supported by the way of the teacher to make the atmosphere more positive to argue something. Teachers are supposed to make the English lesson more interesting, for example, use some media pictures or videos and raise questions that demand students to come up with problems and solutions. Therefore, teacher's creativity plays a role as stated in interview.

Teacher 1:

"The most important thing is teacher's creativity. How the teacher creates a good atmosphere. Using facilities to support the use of digital, such as gadgets or the internet. It can also be through music or videos that students observe and how the teacher raises questions that lead students to think critically."

Teacher 2:

"Some students are also quiet, understand or not, they are just being quiet. Typical students like that we have to ask questions. If they are confused, we ask again. If they don't understand, we just explained. So it is important by giving them critical questions to make them open, from those who do not know to be aware and those who are not active become active."

It was also stated in an interview where the other challenges to promote critical thinking was parental involvement. As stated by both teachers, parents must establish good communication with children, be directly involved with their education by having efforts to communicate, behave openly and being democratic. The following are the statements from the teachers:

Teacher 1:

"Parental involvement has a very important role in influencing students from an early age so they can think critically in problem solving at home. If the father/mother behaves openly to communicate, hears complaints and the willingness of their child or the term is to be democratic. The child will get used to think critically Otherwise, if dictatorial parents impose children's will, they will not be able to grow critical thinking."

Teacher 2:

"Parents must guide their children to be openminded towards anything so as to lead their children to ask questions about everything"

If there was a problem at home, it caused that the students would have not been focus in the class and make their mood unpleasant. This situation where the role of parental involvement is very important. Parents must establish good communication with children, and be directly involved with children's education. Marzano (2003) claims that one of five key factors that influence school achievement is parental involvement. Seeing parents involved in the education of their children is a good thing because it improves academic performance. Students become more focused on their school work (Kwatubana \& Makhalemele, 2015).

The use of English and Bahasa Indonesia was 
also applied in the process of teaching and learning. The teachers tended to use English in Lower-order questions. While, if the teachers promoted Higher-order questions they tended to switch from English into Bahasa Indonesia. Based on the interview, the two English teachers also realized that lack of vocabulary of students as one of the challenges that they faced to promote students' critical thinking. The following are the statements from the teachers:

Teacher 1:

"Indeed the higher the level of the question the more students take time to answer the question. For example, students give a wrong example even though the aim of the teacher is to make students think. Then they realize it is wrong mam, it should be like that. So, the process of learning cannot be just spoonfeeding."

Teacher 2:

"The students who are being frightened mostly scared to ask and answer critical questions. I do not have a problem if their answers are in Indonesia or English, the important thing is for us as a teacher to translate it later. Therefore, if the students' English background is good, it is easy to ask and respond to teachers' questions. It is hard if the students do not understand and not interested in English."

It was also supported by the result of questionnaire that the cause of students' nonresponse was the students could not put ideas into words to answer the questions $(13,53 \%)$ and thought the content of questions was too difficult and complex (8,73\%). (See Table 2)

It could be inferred that students were confused to convey words correctly, especially if they were asked for higher-level questions because they needed to think deeply and they were a lack in a number of vocabularies in English to express their idea. Moreover, based on the observation, the lessons taught were comparison degree and past tense which means asking students to know the correct vocabulary and grammar. It is in relation with study conducted by Arjulayana and Srikandi (2019) who state that the lack of mastery vocabulary is the obstacle by students to communicate by using English.

The teachers knew that the problem is students were afraid to say because they were in lack number of vocabularies related to what level they should behave. EFL school students would need an active vocabulary at least 3000 highfrequency words of English or an average rate of seven words per day (Renandya, 2013). As a matter of fact, how could students elaborate answers that are cognitively demanding to enhance students' critical thinking if students commonly got difficulties in vocabulary and considered vocabulary as difficult aspects. As we know that Indonesia uses EFL (English as Foreign Language), therefore, EFL learners only practice English in the classroom not formed as natural behavior since primary school.

The last due to observation was conducted in two lessons; comparison degree and past tense in 16 meetings, the researchers found out there was no relationship between the lessons teachers taught and the number of higher-order questions asked. Therefore, no matter the material was, the two teachers remained higher-order questions to inject students' critical thinking although only a few questions.

To sum up, the fact that there were Lowerorder questions and Higher-order questions asked by the two English teachers although the percentage of Higher-order questions was very low. This was understandable because the two English teachers in this study have been accomplished Curriculum 13 Training and HOTS (Higher Order Thinking Skills) training so they had been familiar with it. Therefore, the teachers have already known which is Lower-order questions and Higher-order questions although during implementation at the observation the teachers asked dominantly Lower-order questions because the teachers state that the level of students' intelligence has yet to reach the level of Higher-order thinking. However, from the students' perspective, the causes why they did not answer the Higher-order questions were they afraid of making mistakes and lack number of vocabularies in English.

\section{CONCLUSION}

This study examined how critical thinking was implemented in the questions asked by English teachers, the challenges faced by the teachers in integrating critical thinking questions in the classroom, and the students' reasons for nonresponse to questions asked by teachers. Concerning the levels of questions adapted to Bloom's Taxonomy based on Wilen (1991), the result indicated that two English teachers have promoted critical thinking although most of the questions asked by them were in lower-order questions. It does not mean much dominant lower-order questions could not facilitate students' critical thinking, but it could lead students to think critically.

Dealing with the challenges faced by the two 
English teachers in integrating critical thinking questions were students' intelligence has yet to reach the level of Higher-order thinking skills, unconducive-classroom environment, teachers' creativity itself, parental involvement and students' lack of vocabulary.

In the reason for students' non-response in particular questions asked by teachers, there were some reasons behind it. Such as students are afraid of making mistakes, they could not put ideas into words, and lack of vocabularies.

\section{REFERENCES}

Arjulayana, \& Srikandi, C. N. (2019). Early semester student needs in English mastery to support teaching and learning process in English department. The Asian EFL Journal, 24(4.1), 7897.

BAN S/M. (2017). Perangkat akreditasi SMP/MTS. Jakarta: Indonesia Ministry of Education.

Bloom, B. (1956). Taxonomy of educational objectives: The classification of educational goals. New York, United States: Longman, Green and Co ltd.

EF. (2017). Indeks kecakapan bahasa Inggris EF. Retrieved from https://www.ef.co.id/epi/regions/asia/indonesia/.

Indonesia Ministry of Education. (2010). Peraturan pemerintah Republik Indonesia nomor 17 tahun 2010 tentang pengelolaan dan penyelenggaran pendidikan. Jakarta: Indonesia Ministry of Education.

Indonesia Ministry of Education. (2013). Peraturan menteri pendidikan dan kebudayaan Republik Indonesia nomor 81 a tahun 2013 tentang implementasi kurikulum. Jakarta, Indonesia: Indonesia Ministry of Education.

Indonesia Ministry of Education. (2015). 7 provinsi raih nilai terbaik uji kompetensi guru 2015. Retrieved from https://www.kemdikbud.go.id/main/blog/2016/0 1/7-provinsi-raih-nilai-terbaik-uji-kompetensiguru-2015.

Indonesia Ministry of Education. (2016). Peraturan menteri pendidikan dan kebudayaan nomor 22 tahun 2016 tentang standar proses pendidikan dasar dan menengah. Jakarta: Indonesia Ministry of Education.

Katemba, C. V., \& Marie, A. R. (2016). Analysis of teacher's questioning and students' critical thinking in English classroom. Journal of International Scholars' Conference, 1(2), 23-33.

Khan, W. B., \& Inamullah, H. M. (2011). A study of lower-order and higher-order questions at secondary level. Asian Social Science, 7(9), 149157.

Kwatubana, S., \& Makhalemele, T. (2015). Parental involvement in the process of implementation of the national school nutrition programme in public schools. International Journal of Educational Sciences, 9(3), 315-323.

Matra, S. D. (2014). Teacher questioning in classroom interaction. A Journal of Culture: English Language Teaching \& Literature, 14(1), 83-111.

Marzano, R. (2003). What works in schools: Translating research into action. Alexandria, VA: Association for Supervision and Curriculum Development.

National Education Association. (2012). Preparing 21st century students for a global society: An educator's guide to the "Four Cs". Washington, DC: National Education Association

Natthanan, D. (2009). Teachers' questioning techniques and students' critical thinking skills: English language classroom. Doctoral thesis, Oklahoma State University, The United States.

Purnawarman, P., Ratnaningsih, S., \& Gunawan, M. H. (2017). Scientific approach of 2013 curriculum: Teachers' implementation in English language teaching. Journal of English Education, 6(1), 33-40.

Rahmi, R. A., \& Diem, C. D. (2014). Junior high school students' perception of classroom environment and their English achievement. International Journal of Applied Linguistics \& English Literature, 3(3), 41-47.

Renandya, W. A. (2013). Essential factors affecting EFL learning outcomes. English Teaching, 68(4), 23-41.

Richards, J. C., \& Schmidt, R. (2010). Longman dictionary of language teaching \& applied linguistics. London: Pearson Education Limited.

Sano, M. (2014). Critical thinking skills and teachers' questioning behavior in a Japanese University EFL context. Master thesis, The University of Soka, Japan.

Sholikhati, R., Mardiyana., \& Saputro, D. R. S. (2017). Students' thinking level based on intrapersonal intelligence. Journal of Physics, 943, 1-7. doi :10.1088/1742-6596/943/1/012007.

Slameto. (2003). Belajar dan faktor-faktor yang mempengaruhinya. Jakarta: Rineka Cipta.

UNESCO. (2015). Global citizenship education: Topics and learning objectives. Paris: United Nations Educational, Scientific, and Cultural Organization.

Wilen, W. W. (1991). Questioning skills, for teachers: What research says to the teachers. Washington, DC: National Education Association.

Wilen, W. W. (2001). Exploring myths about teacher questioning in the social studies classroom. The Social Studies, 92(1), 26-32. doi: 10.1080/00377990109603972.

Yuliawati, Y., Mahmud, M. \& Muliati, A. (2016). Teacher's questioning and students' critical thinking in EFL classroom interaction. ELT Worlwide, 3(2), 232-246. 